\title{
O ESTÁNDAR PROSÓDICO
}

\author{
Elisa Fernández Rei
}

Instituto da Lingua Galega (USC)

\section{INTRODUCIÓN}

Habitualmente, ao escoitarmos falar de estándar oral, pensamos sobre todo na axeitada pronuncia e asignación de vogais abertas e pechadas, na correcta realización de determinados sons (xeralmente, os que non existen en castelán), etc., pero sen dúbida tamén se nos veñen á cabeza certos aspectos prosódicos, como a entoación. Aínda así, nos traballos sobre o estándar oral o tratamento do nivel prosódico, que abrangue máis aspectos cá entoación, ocupa un segundo plano ou, no mellor dos casos, é o epígrafe final. Así pois, a razón de tratar por separado a compoñente prosódica do estándar é que quero outorgarlle un lugar de maior relevancia e tratalo coa demora que require. Deste xeito, desvinculado, ata certo punto claro, da fonética segmental, apreciaremos mellor as súas peculiaridades non só no eido da prescrición, senón tamén no da descrición. Polo que se refire á perspectiva prescritivista, é manifesta a maior dificultade de codificación dos aspectos prosódicos (de feito, case todo o que ata agora se formalizou do estándar oral pertence ao nivel segmental); en canto á perspectiva de intencións descritivas, o grao de desenvolvemento que presentan os estudos sobre o nivel segmental é moito maior có dos dedicados ao nivel suprasegmental. Finalmente, cando falamos de estándar oral, referíndonos ao plano segmental, movémonos sempre dentro do lingüístico; porén, cando tratamos a entoación, por exemplo, estamos bordeando terreos nos que ás veces é moi difícil dirimir que significados son lingüísticos e que outros son paralingüísticos (vid. Ladd 1996 e Sosa 1999).

En calquera caso, a pertinencia do título e, en consecuencia, do tema que trato susténtase na necesidade que parece existir de que se proporcione algunha orientación sobre a prosodia e, en especial, a entoación. Teño escoitado en non poucas ocasións a moita xente, recoñezo que do medio académico, queixarse da entoación dos locutores da televisión e definila mesmo 
como unha "copia do castelán". Moitos dos profesionais que traballan nos denominados gabinetes de normalización en medios de comunicación audiovisual teñen exposto a necesidade de contar cunhas pautas que lles axuden a depurar esas entoacións que tan mal soan a algúns. Desde este punto de vista, parece logo necesario que se leve a cabo un labor de prescrición neste campo.

Con todo, hoxe pretendo ademais presentar o labor que se leva feito no ámbito da descrición prosódica do galego, para tratar así a variación na prosodia e facer unha comparación entre distintas variedades na medida en que o desenvolvemento dos estudos neste campo o permite. En primeiro lugar, vou definir e delimitar o campo da prosodia e presentar o estado da cuestión, para así saber que grao de desenvolvemento teñen os estudos prosódicos de índole descritiva e coñecer, en definitiva, non só qué describe a prosodia, senón tamén canta prosodia galega hai descrita. En segundo lugar, vou intentar poñer de manifesto certas características da prosodia dos medios de comunicación, por ser este un dos principais difusores do estándar, en comparación coas descricións existentes doutras variedades. Por último, repasarei as dificultades ás que nos enfrontamos no labor de prescrición que queiramos facer no terreo da prosodia.

\section{O OBXECTO E O CAMPO DE ESTUDO DA PROSODIA}

Aínda que agora hei reparar naqueles aspectos da descrición da prosodia do galego que son de relevancia para a configuración dun estándar oral, sería conveniente comezar por situar a prosodia no seo da gramática, así como expoñer a orientación teórica e metodolóxica que sigo para a descrición prosódica das variedades lingüísticas.

Polo xeral ao falar de prosodia alúdese fundamentalmente á entoación, o acento e o ritmo. No entanto, a concepción que eu teño de prosodia é algo diferente, se cadra máis ampla, pois non é só un sinónimo do que tradicionalmente se denominaba nivel suprasegmental, é dicir, a descrición daqueles trazos que se estenden máis alá do segmento, senón que por prosodia entendo o sistema de organización fonolóxica alén do fonema: un sistema de estruturación xerárquica das unidades fonolóxicas.

Esta concepción da prosodia está baseada na fonoloxía prosódica, da que son fundadoras Nespor e Vogel (1986). Basicamente, estas autoras presentan unha visión da fonoloxía dentro da gramática da lingua afastada da teoría xenerativa tradicional, no sentido de que esta entendía a fonoloxía como unha organización lineal de segmentos e un conxunto de regras fonolóxicas que tiñan uns ámbitos de aplicación definidos implicitamente en ter- 
mos de lindes na estrutura de superficie do constituínte morfosintáctico: o educto (output) da compoñente sintáctica constituía o aducto (input) da compoñente fonolóxica (Nespor / Vogel 1986). Pola contra, no marco da fonoloxía prosódica, estímase que as regras fonolóxicas non remiten directamente a información morfosintáctica, senón que a compoñente prosódica é a que organiza a cadea sonora en unidades fonolóxicas, formadas a partir da información proveniente das compoñentes morfolóxica e sintáctica.

Phonology is thus a theory of the sonorous interpretation of the strings generated by the morphological and the syntactic components. The interpretation is indirect, mediated by prosodic structure (Nespor 1990: 375).

Estas unidades fonolóxicas, organizadas xerarquicamente, son os dominios $^{2}$ da sílaba $(\sigma)$, o pé $(\Sigma)$, a palabra fonolóxica ou prosódica $(\omega)$, o grupo clítico $(C)^{3}$,a frase fonolóxica $(\phi)$, a frase de entoación (I) e o enunciado fonolóxico (U). Cada unha destas unidades defínese mediante regras de proxección, que incorporan información proveniente das compoñentes morfolóxica, sintáctica e mesmo semántica, das que resultan constituíntes non necesariamente isomórficos dos constituíntes morfosintácticos. As unidades ás que me referirei na análise da elisión vocálica son a frase fonolóxica e a frase de entoación, polo que paga a pena repasar as súas regras de proxección:

\section{(1) Formación de la Frase Fonológica}

\section{I. Ámbito de $\phi$}

El ámbito de $\phi$ consta de un $\mathrm{C}$ que contiene un núcleo léxico $(\mathrm{X})$ y todos los C de su lado no recursivo, hasta llegar al C que contiene otro núcleo situado fuera de la proyección máxima de X.

II. Construcción de $\phi$ Reúnanse en un $\phi$ de ramificación $n$-aria todos los $\mathrm{C}$ incluidos en una secuencia delimitada por la definición del ámbito de $\phi$.

(Nespor / Vogel 1994: 194-195)1

1 Cito pola tradución española indicada na bibliografía.

2 Optamos pola utilización dos mesmos símbolos que empregan Nespor / Vogel (1986) e que son de uso común nas publicacións de traballos de fonoloxía prosódica: $\sigma$ (sílaba), $\Sigma$ (pé), $\omega$ (palabra fonolóxica), $\phi$ (frase fonolóxica). En vez de usarmos as traducións, consideramos máis práctico conservar as letras provenientes do inglés para I (Intonation Phrase $=$ frase de entoación) e $\mathrm{U}($ Phonological Utterance $=$ enunciado fonolóxico), pois evita a multiplicidade de etiquetas que sempre dificulta a lectura e ao mesmo tempo escusa explicacións.

3 Estas autoras inclúen na xerarquía o grupo clítico (C), entre $\omega$ e $\phi$, pero este é un constituínte non aceptado por todos os autores e que foi obxecto de numerosas críticas nos traballos posteriores dentro deste mesmo marco teórico. Pódese ver unha discusión sobre C con exemplos do galego en Fernández Rei (2002). 
Nespor / Vogel (1986) establecen na súa xerarquía prosódica un dominio intermedio entre a palabra fonolóxica e a frase de entoación, o grupo clítico (C). Este constituínte foi moi discutido e son moitos os autores que non o consideran un constituínte da xerarquía prosódica (Booij 1996, Hall 1999, Peperkamp 1999, Selkirk 1996, Vigário 1999), de xeito que se non se quixese considerar na xerarquía a existencia de C, habería que enunciar unha nova regra de proxección para a definición da frase fonolóxica, na que esta non estaría formada por grupos clíticos senón por palabras fonolóxicas (un núcleo léxico e todas as palabras fonolóxicas do seu lado non recursivo).

En (1) vemos que a frase fonolóxica inclúe dentro da súa proxección os complementos do núcleo que se sitúen no seu lado non recursivo. Se aparecen complementos polo seu lado recursivo, pódese producir unha reestruturación, isto é, a unión de dúas frases fonolóxicas nunha soa:

\section{Reestructuración de $\phi$ (opcional)}

Una $\phi$ no ramificada que es el primer complemento de $\mathrm{X}$ por su lado recursivo se agrupa con la $\phi$ que contiene a $\mathrm{X}$.

(Nespor / Vogel 1994: 200)

(2) (2a). [Os rapaces $]_{\phi}[\text { díscolos }]_{\phi}$ son os máis simpáticos

(2b). [Os rapaces $]_{\phi}[\text { dese colexio francés }]_{\phi}$ son os máis simpáticos

(2a) pode reestruturarse e dar como resultado [os rapaces díscolos $]_{\phi}$, posto que $[\text { díscolos] }]_{\phi}$ se sitúa no lado recursivo do núcleo e non está ramificada. Pola contra, en (2b) non se produciría a reestruturación, dado que [dese colexio francés $]_{\phi}$ é unha frase fonolóxica ramificada. Isto quere dicir que se hai algunha regra fonolóxica que teña como ámbito a frase fonolóxica pero non actúe entre frases, esta só operaría en (2a) e non en (2b).

Por riba do nivel da frase fonolóxica atopamos a seguinte unidade na xerarquía, a frase de entoación. Este constituínte presenta peculiaridades importantes con respecto aos que vimos ata agora, en tanto que a natureza da súa definición é máis xeral e que se pode ver afectado por factores ou condicionantes extrasintácticos que non tiñan incidencia ningunha nas unidades situadas máis abaixo na árbore prosódica, por exemplo a velocidade de elocución, lonxitude dos constituíntes, etc.

Nespor / Vogel (1986) propoñen as seguintes regras de proxección e formación: 
(3) Formación de la Frase de Entonación

\section{I. Ámbito de $E[=\mathrm{I}]$}

Una $E$ puede constar de

a. todas las $\phi$ de una secuencia que no esté incorporada estructuralmente al árbol de la oración en el nivel de la estructura-S.

b. toda secuencia de $\phi$ pertenecientes a una oración radical que queden adyacentes tras la aplicación de Ia.

\section{Construcción de E}

Únanse en una E de ramificación n-aria todas las $\phi$ incluidas en una secuencia delimitada por la definición del ámbito de E.

(Nespor / Vogel 1994: 220)

Tamén con respecto á reestruturación da frase de entoación hai diferenzas en relación cos niveis inferiores da xerarquía prosódica, pois normalmente a reestruturación da frase de entoación prodúcese para crear constituíntes máis curtos. Ademais, é moito máis flexible e depende con frecuencia de factores non sintácticos, como a lonxitude dunha determinada secuencia, a velocidade de elocución, o estilo de fala e consideracións especiais de prominencia semántica ${ }^{4}$.

Finalmente, as evidencias de que as regras de proxección definen axeitadamente as unidades prosódicas proveñen da análise das regras fonolóxicas ${ }^{5}$ que teñen como ámbito de actuación os devanditos constituíntes. Aínda que non pretendo estenderme aquí nos fundamentos da fonoloxía prosódica, é importante que se teña en conta que todas as regras fonolóxicas que operan no seo dun determinado dominio ou entre dominios prosódicos son pertinentes para un estudo prosódico.

El subsistema que abordaremos en el presente estudio es el subsistema prosódico y, en particular, la teoría de los ámbitos [ingl. 'domains']. De acuerdo con la teoría prosódica, la representación mental del habla está dividida en fragmentos jerárquicamente organizados. En el fluir típicamente continuo del habla, esos fragmentos mentales, los constituyentes prosódicos de la gramática, están marcados con diferentes clases de señales que abarcan desde modificaciones segmentales en sí hasta cambios fonéticos más sutiles. Esto es, cada constituyente prosódico

4 Vid. Nespor / Vogel 1994: 224-238 para os factores que restrinxen os lugares en que pode aparecer un corte na frase de entoación.

5 Segundo Nespor / Vogel (1994: 27-28) debemos diferenciar as regras de proxección, que representan a interacción entre a compoñente fonolóxica e as outras compoñentes da gramática, das regras fonolóxicas propiamente ditas. As primeiras son regras que definen as unidades da xerarquía prosódica, mentres que as segundas son as responsables dos cambios no patrón fonolóxico. 
actúa como ámbito de aplicación de reglas fonológicas específicas y de procesos fonológicos (Nespor / Vogel 1994: 13).

Así a todo, non só remiten á xerarquía prosódica as regras fonolóxicas, senón tamén outros fenómenos de carácter duracional, relativos á prominencia, rítmicos e entoacionais (Frota 2000). A xustificación dos constituíntes prosódicos pode provir así mesmo de que un determinado dominio sexa o ámbito de restricións fonotácticas (Hall 1999).

Tras esta breve presentación do marco teórico, detereime nalgúns aspectos prosódicos que me parecen de especial relevancia, nomeadamente os procesos fonolóxicos de sandhi e a entoación, por se tratar dos aspectos que mellor poderían servir para caracterizar prosodicamente unhas variedades fronte a outras ${ }^{6}$.

\section{O SANDHI VOCÁLICO}

O termo sandhi externo era utilizado na tradición clásica india para designar aqueles procesos fonolóxicos que operan entre palabras, fronte ao sandhi interno que se reservaba para os que actúan no seo da palabra. Á elisión, que é a regra fonolóxica da que me vou ocupar, acáelle á perfección esa etiqueta de sandhi externo, pois actúa entre palabras:
(4) a. beb[e o] leite
[o]
b. béb[eo]
$[\mathrm{eo}] / *[\mathrm{o}]$
c. víd[eo]
$[\mathrm{eo}] /{ }^{*}[\mathrm{o}]$

Non obstante, Nespor / Vogel (1994: 86) propoñen utilizar o termo sandhi sen adxectivos, dado que na xerarquía prosódica a palabra non ocupa o lugar nuclear ou central, polo que non ten sentido facer unha distinción que tome esa unidade como punto de referencia.

Unha das cuestións que habitualmente xorden en relación coas regras de sandhi é a influencia que ten o estilo de fala no seu comportamento. Así, Dogil (1984) defende que o marco teórico que se empregue para o estudo das regras fonolóxicas debe ser capaz de explicar o seu funcionamento nos diferentes estilos de fala. Segundo este autor, a fonoloxía prosódica proporciona todos os criterios necesarios e suficientes para a descrición da fala rá-

\footnotetext{
6 Tamén cabería aquí falar do fraseo prosódico e, de feito, farei mención del brevemente no seu momento, pero por falta de datos non me deterei coa demora que requiriría.
} 
pida e informal, de xeito que non forza ao investigador a adaptar a teoría ás particularidades que presenten os datos que está examinando:

Let us take, for instance, a rule of nasal assimilation. In slow speech in German, this rule can apply only within scope of a foot $(\Sigma)(\ldots)$. In faster speech, however, the scope of this rule becomes greater; in German it will be a word $(\omega)$, in Italian a phrase $(\phi)(\ldots)$. Prosodic structure, understood as a specific mapping of syntactic structure, also explains the fact why assimilation does not take place in certain contexts (Dogil 1984: 112).

Este modelo teórico permíteme, por tanto, describir non só as distintas variedades dialectais, senón tamén as diferentes variedades estilísticas. Con todo, cabería facer unha observación ás palabras de Dogil, posto que non é o mesmo a fala rápida cá fala informal e as repercusións dunha e doutra nas regras fonolóxicas tampouco son as mesmas: a fala empregada nun rexistro coloquial pode ser máis ou menos rápida, do mesmo xeito que unha velocidade de elocución alta non ten por que implicar que o rexistro sexa informal. Así mesmo, hai procesos fonolóxicos que só se producen, ou que teñen unha maior incidencia, cando se fala rápido, independentemente do rexistro utilizado, mentres que outros só teñen lugar nos rexistros máis coloquiais, aínda que se fale a unha velocidade menor.

Nespor (1987:81) propón unha clasificación das regras de fala rápida: por un lado, os procesos que operan sexa cal sexa a velocidade de elocución, pero que amplían o seu dominio de actuación ao aumentar a velocidade; e, por outro lado, os fenómenos típicos da fala rápida, como por exemplo a desaparición de sílabas. A elisión encadraríase, pois, no primeiro tipo, en tanto que é unha regra sensible á organización da cadea en constituíntes prosódicos, como veremos a continuación, se ben é certo que pode ter unha maior incidencia se se aumenta a velocidade de elocución.

\subsection{Elisión vocálica}

O encadeamento de palabras na fala dá lugar con frecuencia a secuencias de vogais en hiato, para o que as linguas habilitan os mecanismos necesarios que resolvan estes encontros vocálicos. Entre estes mecanismos, dirixidos a crear esquemas máis regulares, está a elisión vocálica, que consiste basicamente en que, dada unha secuencia de vogais, unha delas desapareza, ou ben a primeira vogal da secuencia $\left(\mathrm{V}_{1}\right)$ ou ben a segunda $\left(\mathrm{V}_{2}\right)$. En (5) recóllese un exemplo de elisión de $\mathrm{V}_{1}$ : en (5a) realízase unha transcrición de todo o enunciado, onde ten lugar a elisión da última vogal da palabra "colle"; en (5b) extraio as dúas sílabas que se ven implicadas no proceso de eli- 
sión e ofrezo a sílaba resultante; e en (5c) represento a estrutura silábica das sílabas orixinais e da sílaba obtida tras a elisión. Como podemos ver, prodúcese un cambio na estrutura silábica, xa que se parte de dúas sílabas e obtense, tras actuar a elisión, unha soa sílaba, co ataque da primeira e o núcleo e a coda da segunda.

(5) a.Colle un prato na cociña $\rightarrow$ ['kof um 'prato na ko' $\theta i n a]$

b. ... lle un... $\rightarrow$... llun...

c. $\left.\left.\mathrm{CV}]_{\sigma} \mathrm{VC}\right]_{\sigma} \rightarrow \mathrm{CVC}\right]_{\sigma}$

Así a todo, isto non quere dicir que o galego non permita secuencias heterosilábicas de vogais: hai ítems léxicos que as conteñen (vídeo, abanear, aldea, etc.), aínda que moitos deles, dependendo das vogais implicadas e da posición do acento, poden sufrir procesos de redución como a ditongación ou sinérese (vídeo ['biợjo], etc.). Así mesmo, a sinérese tamén pode aparecer entre palabras para desfacer secuencias hiáticas:

(6) Dixo qu[e o] vira na rúa

[kjo]

En primeiro lugar, farei un repaso dalgúns traballos en que se describiu o funcionamento da elisión vocálica en distintas variedades dialectais; en segundo lugar, enunciarei as regras de elisión tal e como funcionan no dialecto da Mariña luguesa que estudei na miña tese de doutoramento (Fernández Rei 2002); e, finalmente, compararei estes datos co comportamento da elisión noutros textos, seleccionados non pola súa procedencia dialectal, senón por representaren estilos e rexistros de fala distintos.

\subsection{Estudos descritivos dalgunhas variedades diatópicas}

A única gramática que trata con algo de detemento as resolucións dos encontros vocálicos é Freixeiro Mato (1998: 193-205). Dado o carácter desta obra, non se recollen as solucións a estes encontros nunha variedade dialectal concreta, nin sequera se fai referencia á variabilidade dialectal, senón que, a partir dunha descrición do funcionamento na literatura do que el denomina "crases vocálicas", fornece pautas sobre a maneira en que se deberían resolver os encontros vocálicos nun rexistro formal e culto. Así pois, a principal fonte da que proveñen os seus exemplos é a lingua literaria, que, desde o meu punto de vista, non é o corpus idóneo no que basear unha descrición sobre este aspecto da fonoloxía, dado que este tipo de lingua, aínda que pretenda ser un reflexo da fala popular, é unha elaboración, e en moitos casos mesmo manipulación, da lingua con fins literarios: pénsese, 
por exemplo, nas repercusións que poden ter as necesidades métricas e que poden dar lugar a resultados nada habituais na lingua non literaria. Así mesmo, a grafía fracasa xeralmente na representación de certas características fonéticas e fonolóxicas que nun estudo da elisión ou da coalescencia son moi importantes, como por exemplo, o timbre das vogais. Eu suxeriría, en todo caso, facer o camiño inverso: a partir da descrición do funcionamento do sandhi na fala real, describir e interpretar a plasmación destes procesos na escrita literaria.

Antes de pasar a ver algúns traballos dialectais que proporcionan datos moi valiosos sobre o comportamento da elisión, debo facer unha aclaración: tanto nestas obras como na miña tese de doutoramento, da que falarei a continuación, estúdase o comportamento da elisión nas secuencias de vogais átonas e nas secuencias en que unha delas é tónica; porén, aquí só vou ter en conta para a explicación os casos en que as vogais implicadas son átonas, porque determe agora nas secuencias en que aparece unha vogal tónica obrigaríame a falar de aspectos rítmicos que alongarían en exceso a exposición. Volvendo, logo, aos estudos dedicados a variedades dialectais, destaco o de López Castro (1990) sobre o galego do sur da provincia de Lugo e o de Regueira (1989) sobre a lingua do norte da Terra Chá, pois neles dedícaselles unha sección aos encontros vocálicos. López Castro (1990:43-61), baseándose nun corpus de gravacións de fala espontánea (monólogos a partir de temas propostos pola enquisadora e cantigas), repasa os resultados que atopa e clasifícaos. A partir dos seus datos, dedúcese que o [e] átono se elide sempre, estea precedido ou seguido de calquera vogal ${ }^{7}$ :

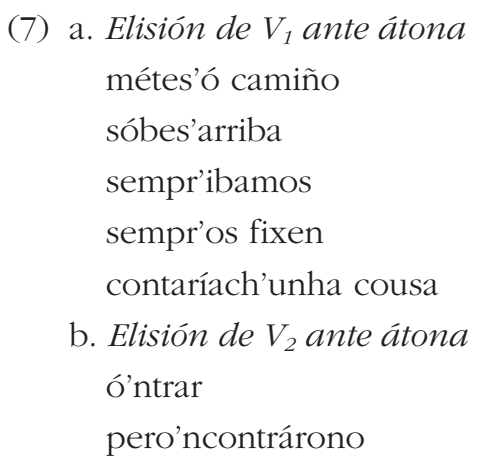

Polo que se refire aos encontros en que está implicada [a] (con vogais distintas de [e]), esta só se ve afectada polo proceso de elisión cando é $\mathrm{V}_{1}$ (se é $\mathrm{V}_{2}$ mantense: $i$-ó apear). Ademais, vemos que os exemplos que se fornecen son só ante [ع] e ante [o] (represéntoos coa correspondente maiúscula):

7 Reproduzo os exemplos coa transcrición ortográfica utilizada pola autora na obra citada. 
(8) a. volt'E volta

b. se se poñíó sol (<se se poñía ao sol)

En canto ao [o] ten algún exemplo de elisión de [o] ante [u] e [o]:

(9) a. fix'un ruído

b. cinc'oras

Regueira (1989: 73-81) tamén extrae exemplos de gravacións da fala popular, a partir dos que elabora uns cadros nos que se recollen os resultados dos encontros vocálicos para as diferentes combinacións de vogais. Fagamos un repaso dalgúns dos exemplos que el atopa no seu corpus:

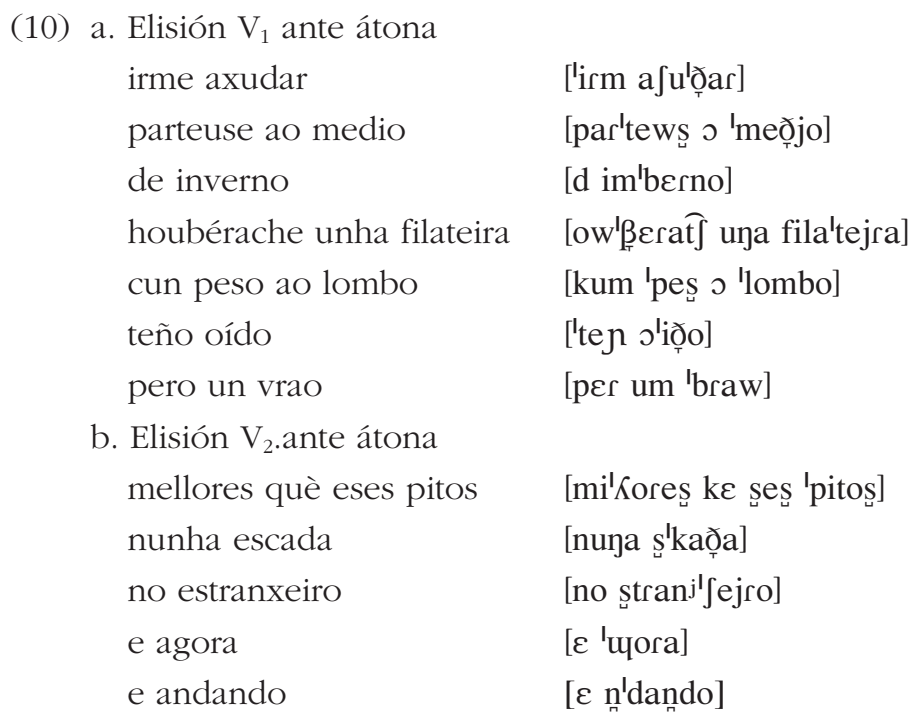

Como veremos a continuación, estas secuencias de vogais dan resultados semellantes na fala por min analizada. No entanto, Regueira (1989: 74) fornece outros exemplos de elisión que xa non aparecerán na variedade que eu analicei:
(11) a. polo peito arriba
[polo 'pejt a'riß̧a]
b. pa un lado e pa outro
[pon' laơ $\varepsilon$ pa 'owtro]
c. bailando igual
[baj'land i'uwal]

Estas combinacións de vogais, nas que Regueira atopa o resultado de elisión, non parecen estar sometidas ao mesmo proceso no dialecto que estudei e que presentarei a continuación. Basicamente, a diferenza consiste en que na fala tratada por el [o] (en posición de $\mathrm{V}_{1}$ ) se elide ante calquera vogal, tónica ou átona (coa única excepción de [e] átono, xa que nese caso é esta 
vogal a que desaparece), mentres que no dialecto da Mariña esta vogal só se elide ante $[\mathrm{o}]$ e $[\mathrm{u}]$ átonos (igual que ocorría no dialecto descrito por López Castro).

Con todo, as diferenzas entre o estilo de fala estudado por Regueira (1989) e o estudado por min en Fernández Rei (2002) son substanciais: el toma os datos da fala espontánea, nunha variedade popular e nun rexistro máis ou menos coloquial, mentres que os meus exemplos proveñen de fala de laboratorio. Ademais, aínda que entre os seus informantes hai algún máis novo, a meirande parte deles supera os sesenta anos e non conta con estudos superiores, fronte ás miñas entrevistadas que teñen idades comprendidas entre os vinte e os trinta anos e posúen formación universitaria. Por tanto, é posible que non atopase elisións nalgunhas secuencias a causa do tipo de fala do que partín e poida que os resultados fosen diferentes se empregase fala espontánea e a idade das informantes fose máis avanzada. Así a todo, non me parece probable, dado o meu coñecemento do dialecto e dado que os resultados atopados por López Castro (1990) son semellantes aos meus, a pesar de que o estilo de fala do que parte e o tipo de informantes que emprega son similares aos que viamos en Regueira (1989).

\subsection{Estudo prosódico do sandhi nun dialecto da Mariña luguesa}

Acabo de repasar brevemente os exemplos que fornecían os traballos previos e que proviñan das ocorrencias atopadas en corpora libres (non deseñados especificamente para observar a resolución dos encontros vocálicos). No estudo que levei a cabo na tese (Fernández Rei 2002) partín dun tipo de corpus moi diferente: tratábase dun conxunto de enunciados deseñado especificamente para o estudo das resolucións dos encontros vocálicos co obxectivo de investigar como estas solucións se vían condicionadas por factores prosódicos.

Antes de comezar a exposición pormenorizada deste traballo, permítaseme facer un par de observacións xerais: todos os procesos de elisión vocálica que trato presentan resultados moi semellantes, isto é, aínda que as vogais afectadas sexan diferentes en cada caso, o seu comportamento segundo as distintas localizacións prosódicas é parello e non observei diferenzas substanciais entre uns e outros; no entanto, os resultados son diverxentes se as vogais implicadas son átonas ou algunha delas é tónica, polo que neste caso si deben tratarse por separado. Ata agora só fixen mención ao comportamento das vogais átonas e así farei no que segue, posto que, como xa mencionei anteriormente, os procesos en que se ve implicada unha vogal tónica presentan restricións de tipo rítmico ás que non podo atender neste momento polas razóns devanditas. 
O obxectivo primeiro é formular unha regra que dea conta de todos os casos en que se produce elisión e que prediga todos aqueles en que non é posible. Hai que propoñer dúas regras, unha para a elisión da vogal en posición final de palabra e outra para a elisión cando está en posición inicial de palabra. Estas regras terían nunha primeira formulación esta forma:

(12) a. Elisión de $V_{1}$ (opcional)

$$
\mathrm{V} \rightarrow 0 /[\ldots]_{\omega}[\mathrm{V} \ldots]_{\omega}
$$

b. Elisión de $V_{2}$ (opcional)

$$
\mathrm{V} \rightarrow 0 /[\ldots \mathrm{V}]_{\omega}[\ldots \ldots]_{\omega}
$$

Hai que resaltar que en (12) non se explicitou a restrición que impide que a vogal obxectivo da elisión sexa tónica:
(13) a. Regaloulle un libro porque le a miúdo
[ea] / *a]
b. Regalaríalle un libro se lese $a$ miúdo
[a]

A partir dos resultados observados en traballos anteriores, así como da propia competencia lingüística, enunciei tres regras diferentes para cada unha das vogais que en galego aparecen en posición átona final de palabra: [e] elídese ante calquera vogal, [o] só ante vogais tamén recuadas e [a] ante vogais medias abertas, frontais ou recuadas. Despois, o traballo consistiu en comprobar o funcionamento destas regras nas distintas localizacións prosódicas, co fin de descubrir cales permitían a súa actuación e cales a bloqueaban. A hipótese da que partía era que esta regra operaría entre palabras, pero o límite entre frases de entoación bloquearía a súa actuación:

$$
\begin{aligned}
& \text { (14) a. Elisión de } V_{1} \text { (opcional) } \\
& \mathrm{V} \rightarrow 0 /\left[[\ldots]_{\omega}[\mathrm{V} \ldots]_{\omega}\right]_{\mathrm{I}} \\
& \text { b. Elisión de } V_{2}(\text { opcional) } \\
& \mathrm{V} \rightarrow 0 /\left[[\ldots \mathrm{V}]_{\omega}[\ldots \ldots]_{\omega}\right]_{\mathrm{I}}
\end{aligned}
$$

Vexamos en (15) algúns exemplos de funcionamento da regra de elisión (en cursiva os encontros que se resolven con elisión e en negriña aqueles en que se mantén o hiato):

(15) a. Ese armador visita empresas no Brasil

b. Aquela rapaza ecuatoriana ocultaba moitos datos

c. Esa oficinista cometía omisións graves

d. O coche ocupou a entrada

e. A rapaza ecuatorian $a$ ocultaba moitos datos

f. O xastre, obrigado por aquel home, abriu a caixa forte 
A predición que facía a regra era que a elisión actuaría no seo dunha frase fonolóxica (15a), entre dúas frases fonolóxicas reestruturables (15b) e entre dúas frases fonolóxicas nas que non hai posibilidade de reestruturación (15c). No caso de (15d) e (15e) as vogais susceptibles de seren elididas aparecen entre suxeito e predicado, onde é moi frecuente a introdución dunha fronteira entre frases de entoación, de xeito que a posibilidade de que opere a regra depende da introdución dese límite: se a hipótese inicial é correcta, o proceso de elisión tería lugar só no caso de que non se inserise unha fronteira entre frases de entoación. A inserción deste límite prosódico maniféstase foneticamente a través dunha pausa, moi habitual nestes contextos, e/ou a través de marcas tonais, como os tons de fronteira: no gráfico 1 podemos ver como na realización de $\mathrm{M}$ hai unha continuidade na curva de frecuencia fundamental desde o comezo ata o final, mentres que en A hai un corte brusco na curva de entoación que se produce xustamente no límite entre suxeito e predicado.

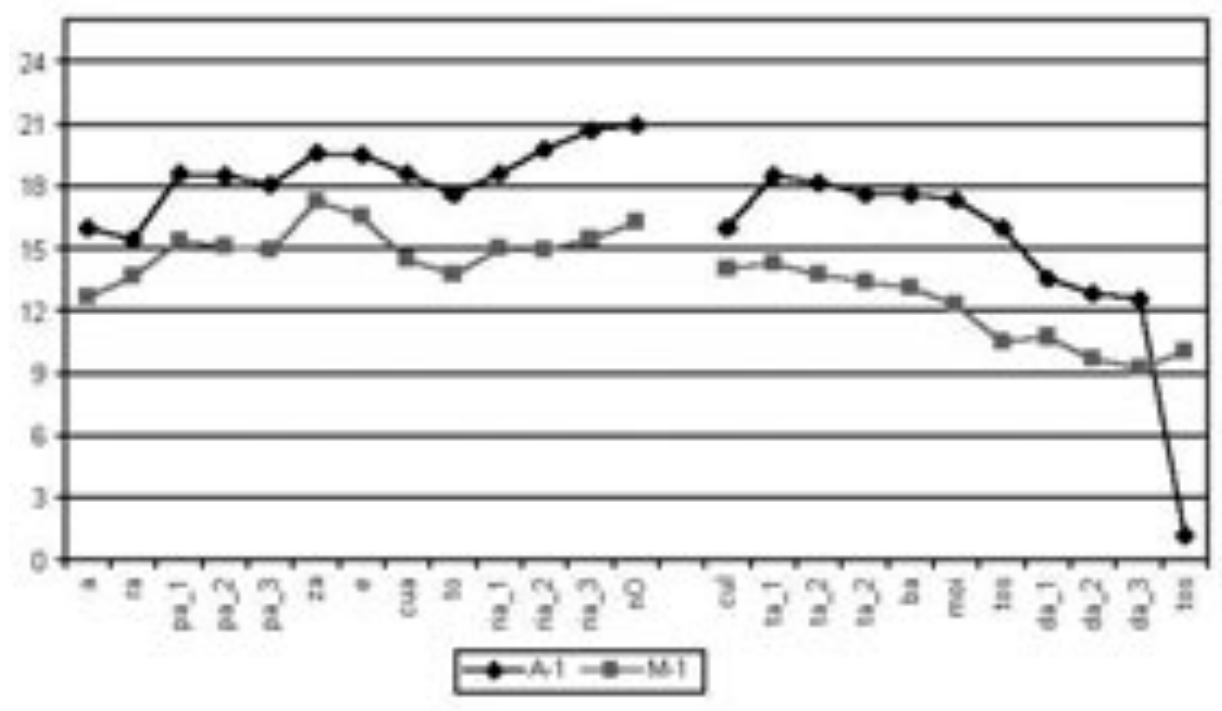

Gráfico 1: Aquela rapaza ecuatoriana ocultaba moitos datos

Así pois, no gráfico 1 pódese comprobar, por unha parte, que hai evidencias entoacionais de que na realización de A se produce a reestruturación dunha frase de entoación en dúas máis pequenas, e, asemade, constátase que a elisión pode actuar no límite entre dúas frases de entoación, posto que tanto nunha coma noutra realización tivo lugar a elisión da vogal.

Por último, en (15f) temos dous exemplos de encontros vocálicos no límite entre frases de entoación, onde a priori non podería producirse a eli- 
sión, aínda que apareceron bastantes exemplos en que si tiña lugar. Estes resultados, xunto cos obtidos nas fronteiras entre suxeito e predicado, leváronme a reformular a hipótese inicial, pois os datos non avalaban que a regra se bloquease na fronteira entre dúas frases de entoación. A solución máis inmediata é propoñer que o ámbito de actuación desta regra sexa o enunciado fonolóxico, o último constituínte da xerarquía. Así pois, en primeiro lugar hai que revisar o comportamento do proceso que nos ocupa na fronteira entre dous enunciados fonolóxicos, para así constatar que a elisión opera no seu seo, pero non no límite entre dous enunciados fonolóxicos diferentes:

(16) a. Non tedes aceite. Oínte chegar

b. Compreivos catro. Oínte chegar

Efectivamente, os resultados corroboran que estaba no certo: o bloqueo da regra nos exemplos de (16) é total. Agora ben, débese ter en conta que os enunciados fonolóxicos son reestruturables baixo certas condicións:

Los EF adyacentes pueden unirse en un solo EF cuando se cumplen las condiciones pragmáticas y fonológicas básicas y cuando existe una relación sintáctica (elipsis, anáfora) y/o una relación semántica positiva (y, por tanto, porque) entre los EF en cuestión (Nespor / Vogel 1994: 282).

As condicións pragmáticas ás que se refiren son que as oracións sexan pronunciadas polo mesmo falante e que as dúas se dirixan ao mesmo ou mesmos interlocutores. En canto ás condicións fonolóxicas, esíxese que as dúas oracións sexan relativamente curtas e mais que non se insira unha pausa entre elas.

(17) a. Non lle toque. Aínda está quente

b. Non lle falaba. Odiábao a morte

En (17) ofrécense un par de exemplos de enunciados fonolóxicos reestruturables, onde en principio podería producirse a elisión, posto as vogais, tras a actuación da regra, xa non se atopan no límite entre dous enunciados fonolóxicos senón entre dúas frases de entoación. No entanto, nestes casos as falantes non realizaban a elisión ${ }^{8}$. Isto colócanos ante unha situación contraditoria: ¿por que a elisión actúa no límite entre frases de entoación no seo dun enunciado fonolóxico, pero non se comporta do mesmo xeito se o

8 Unicamente unha das falantes, N, presentaba unha pequena porcentaxe de elisións neste contexto. 
enunciado fonolóxico é reestruturado? A resposta ten que ver con que baixo a denominación de frase de entoación estamos a agrupar constituíntes fonolóxicos distintos: as frases de entoación que conforman o enunciado recollido en (15f) non son da mesma natureza que as acabo de comentar en (17). Como vimos en $\$ 2$, a xerarquía prosódica non contempla a existencia de ningún constituínte entre a frase de entoación e o enunciado fonolóxico, pero o estudo doutras regras fonolóxicas posléxicas en diversas linguas (Frota 2000, por exemplo) demostraron a necesidade de solventar problemas semellantes ao que aquí estamos tratando e adoptaron unha solución proposta por Ladd (1996): recoñecer a existencia de unidades compostas, é dicir, unidades que teñen como constituíntes inmediatos unidades do seu mesmo tipo. Seguindo esta idea, a reanálise dos enunciados (15f) e (17) daría como resultado que no primeiro caso estariamos ante unha frase de entoación composta $\left(\mathrm{I}^{\mathrm{max}}\right)$ pola súa vez por tres frases de entoación, mentres que no segundo caso estariamos ante un enunciado fonolóxico constituído por dúas frases de entoación compostas9. Deste xeito, en (15f) a elisión opera porque o límite no que se atopan as vogais é de frase de entoación, mentres que en (17) o sandhi non actúa porque existe unha fronteira entre dúas frases de entoación compostas. En conclusión, a elisión pode traspasar o límite entre frases de entoación, pero non entre frases de entoación compostas. A regra de elisión vocálica quedaría definitivamente enunciada como se mostra en (18):

(18) a. Elisión de $V_{1}$ (opcional)

$$
\mathrm{V} \rightarrow 0 /\left[[\ldots]_{\omega}[\mathrm{V} \ldots]_{\omega}\right]_{\mathrm{I}} \max
$$

b. Elisión de $V_{2}$ (opcional) $\mathrm{V} \rightarrow 0 /\left[[\ldots \mathrm{V}]_{\omega}[\ldots \ldots]_{\omega}\right]_{1} \max$

Ata aquí, o desenvolvemento da explicación necesaria para a comprensión do funcionamento da regra de elisión e a xustificación de como se ve afectada por condicionantes prosódicos. Con todo, só vou utilizar unha parte desta información para a comparación desta e das outras variedades dialectais con outras variedades pertencentes a rexistros e estilos de lingua distintos. A razón é obvia: as conclusións tiradas en Fernández Rei (2002) proveñen dun estudo sistemático e deseñado a tal efecto, de xeito que se requiría un inxente traballo de análise doutros rexistros e estilos para que fo-

9 Vid. Fernández Rei (2002) para a xustificación máis detallada deste constituínte e das razóns polas que unha frase de entoación composta pode estar constituída mesmo por tres frases de entoación. 
sen comparables en todos os aspectos alí investigados. Por tanto, voume limitar agora a extraer unha conclusión básica que me servirá para facer unha cala noutras variedades: a actuación da regra de elisión non parece ter ningún tipo de restrición cando actúa entre palabras fonolóxicas no seo da frase fonolóxica ou entre frases fonolóxicas.

\subsection{Variación diastrática e diafásica}

Comezaremos por observar o comportamento da elisión en distintos tipos de textos: dous textos cultos (fragmentos de dúas conferencias), dous textos dun locutor da TVG, un texto extraído dun telexornal da TVG no que aparecen varios locutores ${ }^{10}$ e dous textos narrativos da fala popular ${ }^{11}$. Esta comparación levouse a cabo unicamente nesas localizacións prosódicas que se demostrou non impedían a actuación da regra de elisión. O obxectivo que se persegue é comprobar se a resolución de encontros vocálicos se comporta da mesma maneira nos textos populares de carácter coloquial ca no estándar, así como se a súa incidencia nos medios de comunicación oral é semellante á doutro tipo de textos cultos, que tamén poderían ser tomados como modelos orais de referencia. Tamén se tomarán en consideración os resultados de Fernández Rei (2002), aínda que non se poden considerar representativos da proporción na que este tipo de procesos se dan realmente na fala, porque foron obtidos en condicións de laboratorio e non a partir de fala real.

Coa salvidade xa exposta de que o tipo de corpus de Fernández Rei (2002) é de índole moi diferente, a elisión das vogais átonas en posición de $\mathrm{V}_{1}$ ante vogais átonas ${ }^{12}$ producíase alí de maneira xeneralizada tanto dentro das frases fonolóxicas como entre frases fonolóxicas: entre o 75-90\%, dependendo das falantes ${ }^{13}$. No caso da elisión de $\mathrm{eV}_{2}$, tiña lugar de maneira xeneralizada no seo da frase fonolóxica (100\%, tanto na simple coma na reestruturada) e descendía na fronteira entre dúas frases fonolóxicas para situarse entre o $75 \%$ e o $100 \%$.

${ }^{10}$ As transcricións dos textos dos telexornais utilizadas son resultado do traballo realizado no proxecto de investigación Desenvolvemento dun sistema de transcrión automática de noticias, financiado polo Ministerio de Ciencia y Tecnología (TIC2000-1104-C02-02), pola Xunta de Galicia (PGIDT01PX132201PN) e pola Televisión de Galicia.

${ }^{11}$ Os textos das conferencias, así como os dunha das narracións populares son gravacións pertencentes ao Arquivo Dialectal da Lingua Galega do Instituto da Lingua Galega. A outra narración popular é unha gravación e transcrición recollida en Regueira (1989).

${ }^{12}$ Só efectúo a comparación da elisión de /e/, dado que son os exemplos máis numerosos, entre outras causas, porque se eliden ante calquera vogal.

13 Tiña un total de 1595 exemplos de vogais átonas en posición final ante vogais átonas, en distintos contextos prosódicos e realizados por cinco informantes distintas. 
Se agora tomamos os datos extraídos dos textos antes mencionados, atopamos que o comportamento da elisión varía en función do estilo de fala do texto. Así, nos textos populares (19) parece haber unha clara tendencia a que actúe a elisión (100\% dos exemplos, tanto no seo da frase fonolóxica coma entre frases fonolóxicas distintas), fronte aos textos procedentes dos medios de comunicación (20), onde vemos que a presenza deste proceso se reduce de maneira drástica: opera a elisión no 40\% dos contextos posibles, aínda que é máis frecuente no seo da frase fonolóxica $(48,57 \%)$ ca entre frases fonolóxicas $(20 \%)^{14}$.

(19) Textos populares
a. torre d[e $\varepsilon]$ rcules
$[\varepsilon]$
b. e púxos[e o] quilo de uvas
[o]
c. acercous[e ar] fonte
[a]

(20) Textos dos telexornais
a. sufriu cortes d[e $\varepsilon$ ]lectricidade
[ع]
b. est[e a]mbicioso proxecto
[ea]
c. recomendoull[e ai] poboación
[a]
d. superárons[e o]s cen litros
[eo]

Tras unha primeira análise, advertín que existían comportamentos diverxentes entre os xornalistas, polo que efectuei unha segunda análise máis pormenorizada xebrando os datos dos distintos locutores. Así, identifiquei un dos locutores, fixen un estudo do funcionamento da elisión en varias das noticias que lía e descubrín unha notable diferenza na presenza da elisión neste locutor con respecto aos outros $(66,66 \%$ no seo da frase fonolóxica e $33,33 \%$ entre frases fonolóxicas).

Entre un extremo e outro sitúanse os textos cultos e dun rexistro formal procedentes de conferencias (21), onde vemos que tamén hai unha incidencia importante do sandhi, aínda que non nunha proporción tan alta como a que se aparecía nos textos populares: $87,5 \%$ no seo da frase fonolóxica e 66,66\% entre frases fonolóxicas.

(21) a. entr[e a] grande catástrofe que supuxo... [a

b. de tanta frustración d[e i]deais [i]

c. forma de ser e d[e e]star [e]

d. está aí patent[e $\varepsilon]$ presente $[\varepsilon]$

${ }^{14}$ Esta menor incidencia da elisión podería interpretarse como consecuencia de se trataren de textos moi próximos á lectura. Con todo, os enunciados usados na miña tese tamén están lonxe de seren fala oral espontánea e porén as porcentaxes de elisión son moito maiores. 
Non creo que destes datos se poidan tirar conclusións definitivas, pero si apuntan nunha determinada dirección: a actuación da regra de elisión parece verse condicionada pola variación diafásica e diastrática, en tanto que actúa en maior ou menor medida dependendo do rexistro e do nivel de lingua utilizados. Este distinto comportamento dos encontros vocálicos dependendo do estilo de fala usado xa fora sinalado en Regueira et alii (1998) no seu método para a práctica da pronuncia:

[As alteracións producto dos encontros vocálicos] dependen do ritmo de locución, do rexistro que se está a utilizar e de características individuais. Nun enunciado pronunciado cun ritmo rápido e nun rexistro coloquial producirase un número maior de contraccións e reduccións vocálicas ca nunha locución lenta e nun discurso formal (Regueira et alii 1998: 33).

Con todo, Regueira e os seus colaboradores establecen unha relación entre ritmo rápido e rexistro coloquial, por un lado, e locución lenta e discurso formal, por outro lado, malia non seren factores necesariamente asociados. Non estudei nin comparei a velocidade de elocución nos distintos textos que usei neste traballo, así que non podo presentar datos que o demostren, pero si se percibe que non son os textos coloquiais nos que os informantes falan máis rápido, nin tampouco son os textos formais os que sistematicamente presentan unha menor velocidade de elocución.

\subsection{O sandhi e o estándar}

Ata aquí estiven a falar da descrición da elisión en distintos traballos dialectais e expuxen o aparello teórico necesario para a descrición da elisión e dos factores prosódicos que condicionan a súa actuación. Así mesmo, presentei unha parte dos datos atopados en Fernández Rei (2002) e que me permitiron facer unha comparación entre variedades diastráticas e diafásicas distintas tendo en conta as distintas localizacións prosódicas. Agora ben, unha vez que se atoparon indicios da existencia dunha notable diferenza na incidencia da elisión nos distintos rexistros e niveis de fala, podemos discutir cal se considera que sería o comportamento correcto da resolución de encontros vocálicos na lingua estándar ${ }^{15}$.

\footnotetext{
${ }^{15}$ Aquí estou a traballar unicamente coa elisión, pero isto mesmo se podería aplicar a outros fenómenos de sandhi como a coalescencia, que presentan un comportamento presumiblemente parello (vid. para a coalescencia Fernández Rei 2002).
} 
Vimos que non todos os dialectos se comportan do mesmo xeito: lémbrese, por exemplo, que en Regueira (1989) se recollían certas solucións inexistentes en López Castro (1990) ou Fernández Rei (2002), nomeadamente a elisión de /o/ en posición átona final. Por conseguinte, en primeiro lugar habería que resolver a cuestión de que dialecto se toma como modelo, aqueles en que a vogal /o/ só se elide ante vogais recuadas arredondadas ou aqueloutro en que se elide ante calquera que sexa a vogal que apareza a continuación. Ademais, estes datos refírense só aos traballos que eu revisei, pero hai que ter en conta que existen e que se poderían aínda realizar outras descricións dialectais que poderían fornecer novos resultados e, en consecuencia, outras posibilidades nas resolucións dos encontros vocálicos.

Non hai moitos intentos de prescrición neste campo, pero xa mencionei anteriormente a gramática de Freixeiro Mato (1998), que representa unha desas poucas tentativas, e do que vou reproducir un fragmento no que se ofrecen unhas directrices claras sobre que crases, segundo a súa terminoloxía, se deben producir:

Nese modelo [fonético culto para a lingua oral] e só a modo de aproximación reflexiva, talvez houbese que consagrar entre os encontros vocálicos resoltos oralmente en crase só os dos clíticos en -e seguidos doutra vogal inicial de palabra (de ouro, que eu, non me opoño, xa lle ouvín a voz) e o encontro de vogais átonas homólogas (colle estoutro, na aldea, dixo o neno) (...).

En definitiva, a fonética culta do galego debe preservar a identidade da lingua, mais tamén a clareza e a comprensión. Así mesmo, debe ofrecer un modelo común onde todos se poidan sentir identificados, desbotando fenómenos non xeneralizados que poden desfigurar a necesaria identificación das unidades lingüísticas, e primando as realizacións plenas e máis proprias dun rexistro formal e culto (Freixeiro Mato 1998: 216).

Estou de acordo con que as elisións en de ouro ou de auga poderían ser cualificadas como apropiadas para ese "modelo común onde todos se poidan sentir identificados", porque é unha solución eu diría que xeral na lingua popular, aínda que podería poñer varios exemplos tirados dos textos cultos que analicei nos que tal elisión non se produce. Agora ben, non creo que poidamos meter no mesmo saco exemplos, que segundo as súas indicacións se comportarían igual, pero que como vemos en (22) non se ven afectados pola elisión nin por outro tipo de crase:

(22) a. Dille qu[e a]bro eu *[a]

b. Non m[e a]nda *[a]

c. Non quere falarll[e o]xe ${ }^{*}[\mathrm{o}]$ 
Xunto a isto, tamén podería sinalar exemplos de encontros vocálicos que se resolven de maneira xeral coa elisión e que aí non aparecen contemplados, como por exemplo a elisión de /e/ en posición de $\mathrm{V}_{2}$ :

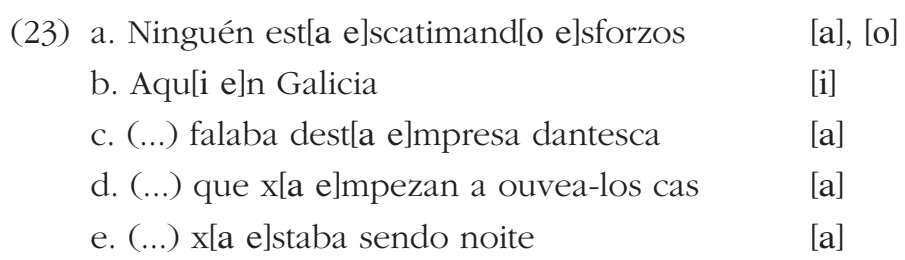

(23a-b) son dos medios de comunicación, (23c) dunha conferencia e (23d-e) dun texto popular.

En (22) danse restricións rítmicas, pois trátase en todos os casos de clíticos rematados en /e/ ante vogais tónicas, que ademais en (22b) e (22c) por$\tan$ o acento do enunciado, e que dan lugar a un clash acentual que bloquea o sandhi. Así, o relevante non é que sexan clíticos, senón as condicións rítmicas que van propiciar ou, neste caso, impedir a elisión. Obsérvese que dos exemplos que proporciona Freixeiro Mato no texto antes reproducido só se produce a elisión ante vogal tónica no caso da preposición de, porque co resto dos clíticos todos os seus exemplos son ante vogal átona. Por tanto, á hora de elaborar unhas pautas para o uso da elisión ou doutros procesos de sandhi vocálico non hai que esquecer que o seu funcionamento está condicionado prosódica e ritmicamente (Fernández Rei 2002) e, daquela, cómpre facer referencia a isto e explicar os contextos nos que a podemos usar. Por outro lado, habería que ter máis datos sobre a súa incidencia nos textos de diferentes estilos para así podermos falar con certa rigorosidade de que procesos son certamente xeneralizados e cales son minoritarios ou particulares dunha determinada variedade.

Finalmente, outra cousa ben distinta é se estamos de acordo ou non coa afirmación deste autor de que no estándar se deben primar "as realizacións plenas e máis proprias dun rexistro formal e culto”. Destas palabras infírese que a lingua estándar só posúe un rexistro, formal, e un nivel de lingua, culto, de maneira que non se recoñece ningunha variación no estándar. En consecuencia, cabe preguntarse se se utiliza o mesmo rexistro e o mesmo nivel de lingua dando un telexornal que retransmitindo un partido de fútbol, posto que, se esas dúas actuacións non son unha mesma variedade, deberiamos deducir que só é estándar a lingua usada no telexornal. Daquela, xurdiría a dúbida da etiqueta que deberiamos outorgarlle á variedade que emprega o locutor de deportes ou á que utilizan os personaxes de Os luns ao sol cando falan das súas cousas no bar. Eu considero que si existe a variación diafásica na lingua estándar e, por tanto, as diferentes variedades sinfásicas 
presentan características propias, de xeito que, probablemente, nos rexistros máis coidados e cultos do estándar non poidan aparecer as elisións da maneira tan xeneralizada en que o fan na lingua popular, pero isto non quere dicir que noutras variedades do estándar máis coloquiais e próximas á fala real deban estar totalmente ausentes ou que se deban primar as realizacións plenas. En todo caso, non se debería perder de vista que non se está aquí dirimindo se un proceso fonolóxico debe ter presenza ou non no estándar, senón que o que parece estar en cuestión é a proporción en que debería aparecer, isto é, discútese sobre a cantidade de elisión que debería estar presente. Obviamente, non parece moi fácil facer unha prescrición neste sentido.

\section{ENTOACIÓN}

As regras fonolóxicas de sandhi vistas ata agora permítenme xustificar e explicar a estrutura prosódica, pero no estrato prosódico adóitase situar tamén a entoación e é este un aspecto de especial relevancia para o tema que hoxe trato. A pesar de que eu concibo a compoñente prosódica da linguaxe dun xeito en que a entoación é só unha das súas manifestacións, son consciente de que moita xente que se refire á prosodia dos locutores dos medios audiovisuais está a pensar basicamente na entoación. Por esta razón creo conveniente establecer a relación entre prosodia e entoación. Non é este un traballo doado e tampouco non hai entre os autores unha única postura ao respecto, de feito case nunca se trata de maneira explícita, nin nos traballos sobre a entoación, nin nos estudos dedicados á prosodia. Así a todo, a interrogante de cal é a relación entre entoación e prosodia xorde de inmediato, dado que hai unha unidade da xerarquía prosódica, a frase de entoación, definida en relación coa entoación:

La formulación de la regla de formación de $\mathrm{E}$ se basa en nociones de que la frase de entonación es el ámbito de un contorno de entonación y de que los finales de las frases de entonación coinciden con las posiciones en que se puede introducir pausas en una oración (Nespor / Vogel 1994: 218).

Esta formulación da frase de entoación fai que nos atopemos de maneira recorrente coas seguintes preguntas: ¿coinciden os límites entre as frases de entoación cos límites dos contornos de entoación? e ¿cales son os indicios tonais de que realmente estamos ante un ton de xuntura, un ton que sinala o comezo ou final dun contorno? Unha das posibles respostas é considerar as pausas como indicador inequívoco da existencia dun límite entre dúas frases 
de entoación. Non obstante, é moi probable que se a pausa non vai acompañada doutras marcas tonais, non esteamos ante tal fronteira: pénsese, por exemplo, nunha elocución lenta na que se van inserindo pausas tras cada frase fonolóxica e mesmo tras cada palabra. A cuestión é saber se estamos no límite entre frases de entoación ou nos encontramos ante pausas no seo dunha frase de entoación: a resposta probablemente sexa que só estamos ante unha fronteira se as pausas van acompañadas doutras marcas tonais, como un ton de xuntura ou un alongamento da átona final (ou da tónica se a última palabra é aguda).

Neste momento non dispoño do tempo necesario nin tampouco podería sustentar con datos certas intuicións que teño sobre o tema, pero non quixera deixar de mencionar a relevancia que isto ten para a descrición das distintas variedades, nomeadamente o modelo empregado nos medios de comunicación: estou a pensar en como se organiza o texto en constituíntes prosódicos, como os enunciados fonolóxicos e as frases de entoación, e os eventos tonais a eles asociados; así mesmo, a relativa frecuencia con que nos medios se vulneran certas regras o que fai que non percibamos o cambio de tema pola entoación, senón polo contido da mensaxe.

Volvendo á definición de frase de entoación como unidade fonolóxica, ou prosódica se se quere, dicía que se trata do dominio sobre o que se estende un contorno de entoación. Así pois, aínda que as regras de proxección poñen de manifesto a interrelación existente entre prosodia e sintaxe, é na natureza da propia unidade onde reside a conexión entre prosodia e entoación. Agora ben, abordando esa cuestión desde o lado prosódico, haberá que indagar se se trata dunha relación biunívoca, é dicir, se a todo contorno de entoación lle corresponde unha frase de entoación e se a toda frase de entoación lle corresponde un contorno de entoación independente. Como é fácil de supoñer, as opinións entre os estudiosos son diverxentes, en parte porque con frecuencia se achegan ao problema do fraseo ou ben desde a perspectiva entoacional ou ben desde unha perspectiva exclusivamente prosódica. Sen me estender agora a explicar as diferentes posturas, si destacarei que Frota (2000) propugna unha visión integradora das orientacións entoacional e prosódica ${ }^{16}$ e concibe as propiedades entoacionais como unha clave máis, xunto cos fenómenos rítmicos, o sandhi e outros procesos morfofonolóxicos, para comprender a estrutura prosódica.

${ }^{16}$ Representantes doutras posturas son, por exemplo, Hayes / Lahiri (1991), que defenden que a xerarquía prosódica organiza os dominios prosódicos que son ámbito de actuación das regras prosódicas e, asemade, dos eventos tonais; ou Dresher (1994), que sostén que os dominios relevantes para as regras fonolóxicas se organizan de maneira distinta aos dominios en que operan fenómenos duracionais como o alongamento ou sobre os que se estenden contornos de entoación. 
In this attempt at an integrated approach, (...) prosodic structure is given a pivotal place in phonological structure (...), and sandhi processes, rhythmic, intonational and boundary strength phenomena are seen as possible ways in which prosodic structure manifest itself (Frota 2000: 14).

Deste xeito, unha vez que xa se situou a entoación na compoñente prosódica da linguaxe, pasarei agora a revisar o estado en que se atopan os estudos sobre este tema, cal é o nivel de desenvolvemento da descrición das distintas variedades e, finalmente, repararei nalgúns aspectos arredor do labor de prescrición neste terreo.

\subsection{O estudo da entoación do galego}

Existen poucos estudos dedicados á entoación do galego e só un par deles teñen carácter monográfico, pois a maioría son artigos publicados en revistas e, por conseguinte, de extensión limitada. Contamos cun par de artigos de Prieto $(1972,1986)$ que presentan unha achega fonolóxica á entoación: no primeiro caso propón os trazos distintivos dos contornos tonais en galego (un ton ascendente, [+Ps], para as interrogativas e un ton descendente, [-Ps], para as afirmativas); e o segundo artigo é de índole teórica e nel trata de demostrar que os nós das árbores prosódicas coinciden cos niveis e cos nós das árbores sintácticas, situándose pois dentro da corrente xenerativa máis tradicional. Porén, o traballo clásico no estudo da entoación do galego é, sen dúbida, o de Carril (1973), onde se fai unha caracterización dos distintos tipos de enunciados (afirmativos, interrogativos, exclamativos, imperativos e disxuntivos) mediante unha análise configuracional e de niveis, isto é, distínguense niveis de ton (/1 2 3/) e xunturas terminais (ascendente e descendente). Tamén nos anos setenta, aparece outra contribución importante, a de Porto (1977), que dedica un capítulo do seu libro sobre a fala da comarca ferrolá á entoación. En definitiva, agás neste último caso, no que se describe unha determinada variedade dialectal, no resto dos estudos faise referencia sempre á entoación DO galego, é dicir, hai implícita a idea de que existe unha entoación característica do galego común, e en ningún caso se menciona que a descrición estea baseada nunha determinada variedade. Isto é especialmente resaltable no traballo de Carril, pois é unha descrición que vai ter moita influencia nas que se realicen posteriormente ${ }^{17}$.

\footnotetext{
${ }^{17}$ Só por citar un caso, é na que se basea Freixeiro Mato para facer a descrición da entoación que aparece na súa gramática e que, na mesma liña que Carril, fai referencia ao galego común, pois di poder "establecer diferentes modelos xerais de entoación en galego, sempre suxeitos a variacións polo contexto, por razóns individuais ou mesmo dialectais" (Freixeiro Mato 1998: 236).
} 
Partindo destes antecedentes, no seo do laboratorio de fonética do Instituto da Lingua Galega, realizáronse na segunda metade dos 90 dúas memorias de licenciatura que tratan a entoación de xeito monográfico (Fernández Rei 1995 e Sobrino Pérez 1997 ${ }^{18}$ ). Encádranse dentro do que Ladd (1996: 12) denomina "instrumental approach", isto é, dentro dunha tradición fonética interesada basicamente na identificación dos índices acústicos da entoación en xeral e, nestes casos en particular, na descuberta dos índices acústicos das modalidades oracionais (enunciativas, interrogativas, imperativas...). Estes dous traballos teñen unha orientación moi semellante, aínda que difiren nalgúns aspectos metodolóxicos, como a selección dos informantes ou o mecanismo de obtención do corpus. Con todo, o máis relevante é que se trata de estudos de carácter fonético e de pretensións eminentemente descritivas, onde se presta atención principal á frecuencia fundamental, aínda que tamén se presenten datos sobre a duración. Así mesmo, os dous traballos céntranse unicamente nos enunciados producidos entre pausas, constituídos por un único grupo de entoación, e non abordan o fraseo entoacional, aínda que de maneira tanxencial tratan os enunciados constituídos por grupos de entoación menores. Así a todo, a diferenza fundamental entre ambos é, precisamente, o tratamento da variación e as intencións de describir un modelo común nun e noutro caso: o traballo de Sobrino Pérez é unha descrición dunha variedade dialectal, concretamente a do Baixo Miño, mentres que no caso da miña memoria de licenciatura tratábase de presentar patróns de entoación dos enunciados interrogativos que puidesen ser cualificados de comúns ás distintas variedades, ou se se quere, de patróns cos que os falantes se puidesen sentir identificados.

En Fernández Rei (1995) levei a cabo a elección de informantes que consideraba, a priori, representantes dunha entoación común e evitei seleccionar falantes procedentes de áreas dialectais que supoñía que presentarían unha entoación característica das interrogativas (do Baixo Miño, por exemplo, como despois se demostrou nos traballos de Sobrino Pérez 1997, 1999). Así mesmo, todos eles eran xente nova e con formación universitaria. Este traballo non tiña intención prescritora, pero si pretendía contribuír na medida das súas posibilidades, pois era un traballo de iniciación á investigación e, por conseguinte, con moitas limitacións, á definición dunha entoación que puidese ser recoñecida polos falantes como supradialectal, como estándar. De feito, foron moi poucas as diferenzas observadas entre os patróns de entoación dos informantes escollidos. Vexamos algún exemplo nos gráficos

${ }^{18}$ Pódese acudir a un resumo publicado en Sobrino Pérez (1999). 
2 e $3^{19}$, onde se representan os patróns asociados, en primeiro lugar, a un enunciado declarativo, e en segundo lugar á mesma secuencia nun enunciado interrogativo:

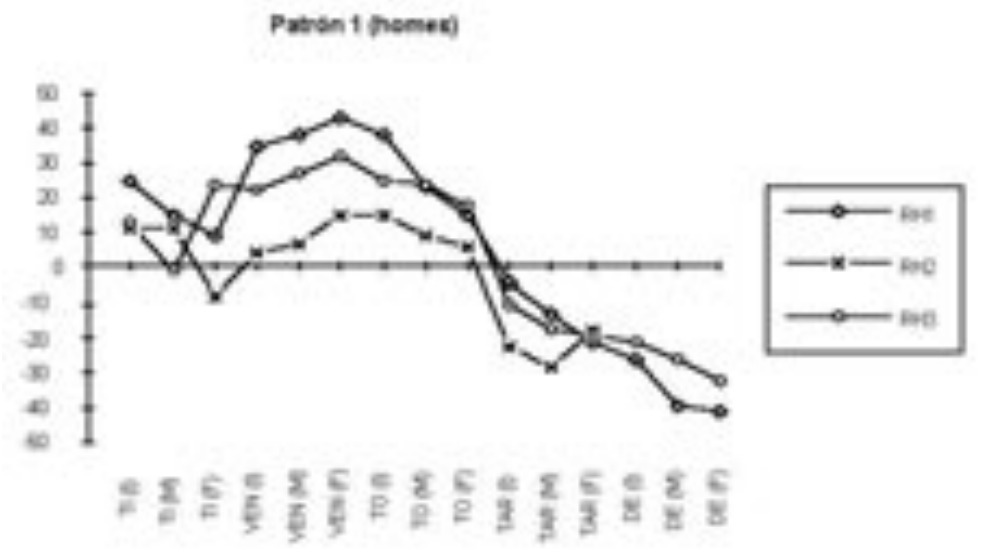

Gráfico 2: Estivo chovendo toda a tarde

Parón 1

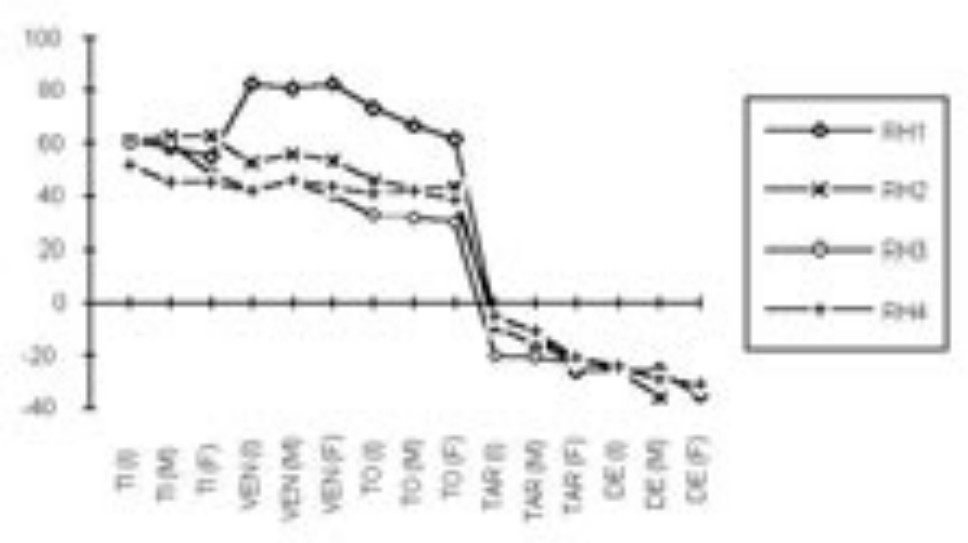

Gráfico 3: ¿Estivo chovendo toda a tarde?

Unha das limitacións do traballo derívase da carencia dun estudo de variación dialectal da entoación, de xeito que, ao estudar un só falante por punto, non sabía de certo se as diferenzas atopadas no comportamento dos informantes se debían a razóns idiolectais ou dialectais. Por esta razón é de

${ }^{19}$ Só se representan os datos das vogais tónicas, pero tómanse tres medidas por vogal (no inicio, no medio e no final). O cero da escala (en hertzios) é a frecuencia fundamental media (calculouse unha para os homes e outra para as mulleres). Os dous gráficos recollen exemplos de informantes masculinos. 
grande relevancia, e vai supor un pulo importante nos estudos da entoación, o proxecto que actualmente estamos poñendo en marcha na Universidade de Santiago de Compostela: o Atlas Multimedia da Prosodia do Espazo Románico (AMPER). É este un proxecto de ámbito europeo, no que se pretende describir a prosodia de todo o dominio románico, facendo unha pesquisa dialectal, na que se recollerá a entoación dos dialectos das distintas variedades romances. Será, por tanto, un paso fundamental na descrición da variación diatópica da entoación do galego, que como acabamos de ver non está moi desenvolvida.

Esta é, de maneira resumida, a situación dos estudos descritivos da entoación. Así, botamos en falta, por exemplo, traballos que se dediquen ao estudo da entoación dos medios de comunicación e que demostren ou boten por terra esa idea tan estendida, e á que fixemos referencia máis atrás, de que a entoación que os locutores presentan é unha copia da do castelán. Con todo, paréceme ese un estudo difícil de levar a cabo, pois se se intenta tomar, por unha parte, un texto dun telexornal galego e, por outra parte, dun telexornal español, atoparanse notables dificultades en tirar exemplos en que as entoacións sexan realmente comparables: teríanse que conseguir frases, en castelán e en galego, sen elementos focalizados, ou de habelos que se sitúen no mesmo lugar no enunciado e sexan do mesmo tipo para que non desvirtúen o conxunto da curva, de estrutura sintáctica semellante, de lonxitude parella, cun tipo de voz o máis semellante posible, etc.

Outra investigación de interese consistiría na comparación dos patróns de entoación que aparecen na fala popular no rexistro coloquial e dos que se utilizan nas dobraxes de películas ou nas series de produción propia da televisión nas que se producen intervencións ou diálogos nese mesmo rexistro. Sería interesante ver ata que punto se trasladan eses modelos populares a unha fala, que aínda que requira un rexistro coloquial, exerce, polo medio a través do que se difunde, a función de modelo de referencia.

\section{Dificultade PARA A CODIFICACIÓN DO ESTÁNDAR PROSÓDICO}

A denominación de "estándar prosódico" encerra un paradoxo: por unha parte, todo o mundo recoñece que se deben dar certas indicacións ou orientacións sobre a pronuncia axeitada no nivel prosódico, pero, por outra parte, creo que todos somos conscientes da inviabilidade de codificar un estándar prosódico. Con todo, habería que facer neste momento unha distinción entre a entoación e os fenómenos rítmicos, por un lado, e os procesos fonolóxicos que presentan condicionamentos prosódicos, polo outro. Estes últimos son, evidentemente, moito máis fáciles de codificar, porque se rexen por unha se- 
rie de regras, aínda que é certo que presentan outro problema distinto, como o de tomar a decisión de que procesos deberían estar representados no estándar e cales non, así como o da proporción na que deberían aparecer.

Moitas veces falamos da depuración de modelos de entoación espúreos e todos parecemos coincidir na conveniencia deste tipo de accións, así como parece que sabemos moi ben a que nos estamos referindo e como se leva a cabo tal depuración. Con todo, se pasamos aos detalles e intentamos dar uns criterios concretos que axuden a determinar que modelos son espúreos e cales non, ou intentamos formalizar dalgunha maneira eses modelos correctos que deberían servir de referencia, as ideas parecen non estar xa tan claras e comezan a xurdir multitude de dificultades. Así mesmo, aínda supoñendo que fósemos quen de confeccionar eses criterios, cabería preguntarse cales serían os modelos alternativos non espúreos que propoñeriamos ou como se codificaría esta información (¿en forma de curvas de entoación?).

Por outra parte, non só se trata de desbotar realizacións entoativas que consideramos alleas ou pouco apropiadas, senón que hoxe en día existen ámbitos que reclaman solucións que van máis alá das listas do que é correcto e do que é incorrecto. As necesidades que aparecen nos medios de comunicación, por exemplo, non se resolven simplemente acudindo aos patróns ou modelos que atopamos na fala corrente ou popular: é un contexto distinto que require un modelo entoativo tamén distinto. Non quero dicir con isto que deba estar necesariamente afastado da realidade lingüística cotiá, nin moito menos que teña que ser unha copia do modelo doutra lingua (portugués ou castelán), pero si considero que non se pode levar a cabo un labor de prescrición de como debe ser, baseándose no coñecemento do comportamento da entoación na fala popular, porque eses modelos non son intercambiables. Creo que estamos ante un aspecto do estándar que se debe ir configurando co uso e que son os propios profesionais os que teñen a maior parte do traballo. Xunto aos profesionais deben estar os correctores lingüísticos, que neste caso deben facer máis ben o labor de correctores de estilo e, guiados pola súa competencia lingüística e polo sentido común, orientar aos locutores, actores, etc.

\section{REFERENCIAS BIBLIOGRÁFICAS}

Booij, Geert (1996a): "Cliticization as prosodic integration: The case of Dutch”, The Linguistic Review 13: 219-242.

Carril, Ramón B. (1973): "Miscelánea. Notas de entonación gallega”, Revista de Filología Española LVI: 95-101. 
Cruttenden, Alan (1986): Intonation, Cambridge University Press, Cambridge. Dogil, Grzegorz (1984): "Grammatical Prerequisites to the Analysis of Speech Style: Fast / Casual Speech", in Dafydd Gibbon / Helmut Richter (eds.): Intonation, Accent and rhythm. Studies in discourse phonology, Walter de Gruyter, Berlín, 91-119.

Dresher, B. Elan (1994): "The prosodic basis of the Tiberian Hebrew system of accents", Language 70-1: 1-52.

Fernández Rei, Elisa (1994): "Contribución ó estudio da entoación das cláusulas interrogativas (totais e parciais) en galego", in Fernández Salgado, Benigno (ed.) (1997): Actas do IV Congreso da Asociación Internacional de Estudios Galegos, vol. I: 241-253, Oxford Centre for Galician Studies.

Fernández Rei, Elisa (1995): Aproximación á entoación dos enunciados interrogativos en galego. Estudio Acústico, Memoria de Licenciatura, Universidade de Santiago (inédita).

Fernández Rei, Elisa (2002): Regras fonolóxicas posléxicas e regras precompiladas de alomorfia sintagmática: dominios prosódicos en galego, Universidade de Santiago, Santiago.

Freixeiro Mato, Xosé Ramón (1998): Gramática da Lingua Galega I. Fonética e Fonoloxía, Edicións A Nosa Terra, Vigo.

Frota, Sónia (2000): Prosody and Focus in European Portuguese. Phonological Phrasing and Intonation, Garland Publishing, Nova York / Londres.

Frota, Sónia / Marina Vigário (2000): "Aspectos de prosódia comparada: ritmo e entoação no PE e no PB”, in R. V. Castro / P. Barbosa (eds.): Actas do XV Encontro da Associação Portuguesa de Lingüística, APL, Coimbra, 533-555.

Hall, T. Alan (1999): "Phonotactics and the prosodic structure of German function words", in T. Alan Hall / Ursula Kleinhez (eds.): Studies on the Phonological Word, John Benjamins, Amsterdam / Philadelphia, 99-131.

Hayes, Bruce / Aditi Lahiri (1991): "Bengali Intonational Phonology", Natural Language and Linguistic Theory 9: 47-96.

Ladd, D. R. (1996): Intonational Phonology, Cambridge University Press, Cambridge.

López Castro, María Xosé (1990): A fala de Sarria (Lier, Calvor, Castelo): estudio fonético e léxico, Memoria de Licenciatura, Universidade de Santiago de Compostela.

Nespor, Marina (1987): "Vowel degemination and fast speech rules", Phonology Yearbook 4: 61-85.

Nespor, Marina (1990): "Vowel deletion in Italian: the organization of the phonological component", Linguistic Review 7: 375-398.

Nespor, Marina / Irene Vogel (1986): Prosodic Phonology, Foris Publications, Dordrecht. Citamos pola tradución española: La Prosodia, Visor, Madrid, 1994. 
Peperkamp, Sharon (1999): "Prosodic Words", GLOT International 4.4: 1516.

Porto Dapena, José Antonio (1977): El gallego hablado en la comarca ferrolana, Verba, anexo 9, Universidade de Santiago de Compostela, Santiago de Compostela.

Prieto Alonso, Domingo (1972): "Un sistema fonolóxico trinario do galego e unha teoría da entoación”, Grial 38: 431-437.

Prieto Alonso, Domingos (1986): "Sobre a intonação do galego", O Ensino 18/22: 199-206.

Regueira Fernández, Xosé Luís (1989): A fala do norte da Terra Cha. Estudio descritivo, Tese de Doutoramento, Universidade de Santiago (inédita).

Regueira Fernández, Xosé Luís (1994a): "Modelos fonéticos e autenticidade lingüística”, Cadernos de Lingua 10: 37-60.

Regueira Fernández, Xosé Luís (1994b): "Elementos para a definición dun modelo fonético estándar da lingua galega”, in Benigno Fernández Salgado (ed.) (1997): Actas do IV Congreso Internacional de Estudios Galegos, Oxford Centre for Galician Studies, vol 1: 179-194.

Regueira Fernández, Xosé Luís (2001): "Acerca de la estructura prosódica del texto: final de enunciado en gallego", in Jesús Díaz García (ed.) (2002): Actas del II Congreso de Fonética Experimental, 301-306, Universidad de Sevilla.

Regueira Fernández, Xosé Luís (coord.) (1998): Os sons da lingua, Edicións Xerais, Vigo.

Selkirk, Elisabeth O. (1996): "The prosodic structure of function words", in James L. Morgan / Katherine Demuth (eds.): Signal to Syntax. Bootstrapping from Speech to Grammar in Early Acquisition, Lawrence Erlbaum Associates, Mahwah, NJ, 187-213.

Sobrino Pérez, María dos Anxos (1997): A entoación do galego do Baixo Miño. Aproximación descritiva, Memoria de Licenciatura, Universidade de Santiago de Compostela.

Sobrino Pérez, María dos Anxos (1999): "A entoación do galego do Baixo Miño. Aproximación descritiva”, Cadernos de Lingua 20: 97-125.

Sosa, Juan Manuel (1999): La entonación del español. Su estructura fónica, variabilidad y dialectología, Cátedra, Madrid.

Vigário, Marina (1999b): "On the prosodic Status of Stressless Function Words in European Portuguese", in T. Alan Hall / Ursula Kleinhenz (eds.): Studies on the Phonological Word, John Benjamins, Amsterdam / Philadelphia, 254-294. 